\title{
Empathy in medical students of Córdoba, Argentina
}

\author{
María J. Ulloque, Magister ${ }^{a}$, Silvina Villalba, M.D. ${ }^{a}$, Teresa Varela de Villalba, M.D. ${ }^{a}$, \\ Adrián Fantini, Medical Specialist ${ }^{a}$, Susana Quinteros, Medical Specialist ${ }^{a}$ and \\ Víctor Díaz-Narváez, PhD. ${ }^{b}$
}

\begin{abstract}
Introduction. Physicians' empathy is an advantage for a better patient care and resolution of disease, and is considered a relevant part of professional training.

Objective. To measure the level of empathy and its components in medical students of the city of Córdoba, Argentina.

Methods. This was an exploratory, cross-sectional study. The Jefferson Scale of Physician Empathy was administered, in its Spanish version for health sciences students (version S), validated in Mexico and Chile, and culturally adapted to Argentina based on experts' opinion. A twofactor analysis of variance (model III) was used to assess mean differences between sexes and school years, and the interaction between these factors. Results. 306/497 students from first through fifth year assessed in November 2016. The sample was stratified by school year and sex. Significant differences were observed in overall empathy and in compassionate care in both factors. These differences increased over the years (higher among fifth year students and lower among first year ones), and women showed higher values than men in terms of empathy and compassionate care. compassionate care component specifically, increased from first through fifth year (and were higher among women compared to men), which evidenced the progressive development of the affective component of empathy. The percentage of development of overall empathy and the cognitive components showed little progression. Keywords: professional training, medicine, students, empathy.
\end{abstract}

a. School of Health Sciences, Universidad Católica de Córdoba, Argentina.

b. School of Health Sciences,

Universidad de Atacama, Copiapó, Region III, Chile.

E-mail address:

María J. Ulloque:

Magister: mjulloque@

yahoo.com.ar

Funding:

Universidad Católica de Córdoba, Argentina, Research Secretariat, project code: 80020150200082 CC.

Conflict of interest:

None.

Received: 12-19-2017

Accepted: 8-15-2018

http: / / dx.doi.org/10.5546/ aap.2019.eng.81

To cite: Ulloque MJ, Villalba S, Varela de Villalba T, Fantini A, et al. Empathy in medical students of Córdoba, Argentina. Arch Argent Pediatr 2019;117(2):8186.

\section{INTRODUCTION}

Empathy has been described as the synthesis of two core components: ${ }^{1}$ cognitive empathy, which is the ability to understand the experience and feelings of other people and the capability to observe and understand the world from another person's perspective, and emotional empathy, which relates the affective aspect to the ability to share the experiences of others. ${ }^{2,3}$ The contribution of social determinants to both individual and collective health has been gaining relevance in medical training programs, together with students' involvement in the care of vulnerable populations. Empathy is recognized as a manner of binding students and patients together, but there is still scarce evidence on how to help students develop such skill in favor of these populations. ${ }^{4}$

At present, numerous factors have an effect on health care providers' practice: the economic crisis, excessive technicality, and bureaucracy, which account for the deterioration in empathy, integrity, solidarity, altruism or confidentiality. ${ }^{5}$ Published studies have demonstrated the advantages of physicians' empathetic manner for a better patient care ${ }^{6,7}$ and, when the patient-doctor relationship is positive, there are more possibilities of disease resolution or maintenance of health status; therefore, this is an essential element in medical practice. ${ }^{7,8}$ It is worth noting the importance of developing empathy in pediatrics because it contributes to a more favorable doctor-patientfamily relationship and, therefore, an improved health care, thus playing an 
active role in a pediatric patient's health care and recovery. ${ }^{9}$

Medical students' empathy, and its components, have been assessed in different countries of Europe, Asia, Latin America and also in the United States of America; ${ }^{1,2,4,6,7,10-16}$ however, no studies have been published on how they work in medical students attending Argentine universities.

The objective of this study was to measure the level of empathy and its components in medical students of the city of Córdoba, Argentina.

\section{POPULATION AND METHODS}

This was an exploratory, cross-sectional study conducted in the context of the Helsinki guidelines. The population was made up of students from the first through fifth year of the school of Medicine of Universidad Católica de Córdoba (UCC), Argentina. Data were collected in June 2016. The Jefferson Scale of Physician Empathy (JSPE) was administered, in the Spanish version for medical students (version $S$ ), which had been validated in Mexico and Chile, ${ }^{17,18}$ and culturally adapted to Argentina based on experts' opinion, ${ }^{19}$ which had also been used in the study by Díaz et al. ${ }^{6}$ In addition to the construct of overall empathy (E), its three components or domains were analyzed: compassionate care (CC), perspective taking (PT), and ability to stand in someone else's shoes (ASSES). The scale was administered confidentially (neutral operator), once participants had signed the informed consent. Students' comprehension of the culturally adapted scale was pilot-tested. Data were tested for normality (KolmogorovSmirnov) and homoscedasticity (Levene). The internal reliability of data was measured using the total Cronbach's alpha and this statistics' values as each element was removed (questions), an intraclass correlation coefficient, Hotelling's T ${ }^{2}$ distribution, and Tukey's test of non-additivity were estimated. The mean and standard deviation were also estimated. A two-factor analysis of variance (ANOVA) (model III) was done to establish mean differences between sexes and school years, and the interaction between these two factors. Data were described using single arithmetic diagrams and processed with the SPSS $22.0^{\circledR}$ statistical software. The percentage of development (PD) was considered the quotient between two magnitudes: a) the effective difference between the scores observed in fifth year students minus the score observed in first year students (D1) compared to b) the possible difference between the highest empathy value permitted by the scale (140) in relation to the effective empathy value among first year students (D2): PD = D1/D2. The PD is an indicator that shows the extent of progression in empathy levels that may be observed in cross-sectional and longitudinal studies. The significance level was established at $\alpha \leq 0.05$ and $\beta \leq 0.20$ in all cases.

\section{RESULTS}

The population was made up of 497 medical students; a sample of 306 was analyzed $(61.57 \%$ of the total). The sample stratified by school year was as follows: first year $=49$, second year $=40$, third year $=95$, fourth year $=46$, and fifth year $=76$. In terms of sex, the sample was distributed into 195 female students and 111 male students. The total student population was not analyzed because a) they were absent or late for class (125 students) on the day the scale was administered, b) the instruments were not fully completed (36 students); or c) they did not agree to participate voluntarily (30 students). The scale was not administered to students who were absent to prevent any potential answer contamination. The results of the mean and standard deviation of the study outcome measures and the sample size for each level and combination of the two factors that were analyzed for overall empathy and each of its components are shown in Table 1.

The Kolmogorov-Smirnov test and the Levene test were not significant $(p>0.05)$; data were distributed normally and showed homoscedasticity. Cronbach's alpha values were satisfactory (non-typified $=0.766$; typified $=0.789$ ), and this suggested that data displayed internal reliability. The total Cronbach's alpha value, if an element (question) was removed, ranged between 0.744 and 0.777 ; and it was inferred that the test showed a high reliability, regardless of the removal of any element. The intraclass correlation coefficient was $0.766(\mathrm{~F}=4.27, p=0.001)$, which confirmed that data were adequately reliable. Hotelling's $\mathrm{T}^{2}$ test $(\mathrm{F}=114.3, p=0.001)$ and Tukey's test of nonadditivity $(\mathrm{F}=10.32, p=0.001)$ allowed to infer, in the first case, that the mean values of questions differed from one another. This demonstrated that not all questions provided the same value to the overall mean (5.64) and showed variability among the answers of the scale. In the second case, it was inferred that data showed no additive effect (it 
required a sample increase); the methods used for analysis proved to be adequate.

Table 2 shows the ANOVA results applied to empathy and each of its components. It was observed that, for E, the school year (SY) factor was significant $(\mathrm{F}=2.73, p=0.029)$; the highest value was observed in fifth year and the lowest one, in second year (Table 1, Figure 1.a); the Etasquared (0.036) and the observed power (0.752) were satisfactory; the sex $(S)$ factor showed highly significant differences $(\mathrm{F}=8.05, p=0.005)$ and the mean value was higher among women than men (Table 1); the Eta-squared value was 0.026 and the power, 0.807 , and both values were satisfactory. For the CC component, significant differences were observed in the SY factor $(\mathrm{F}=2.45, p=0.045)$; the highest value was recorded in fifth year students and the lowest one, in first year students; the Eta-squared (0.032) and the observed power (0.788) were satisfactory. In

TABLE 1. Estimation of scores for overall empathy (and each of its components) by school year and sex

\begin{tabular}{|c|c|c|c|c|c|c|c|c|c|c|}
\hline \multirow[t]{2}{*}{$\begin{array}{l}\text { School } \\
\text { year }\end{array}$} & \multirow[t]{2}{*}{ Sex } & \multicolumn{2}{|c|}{ Empathy } & \multicolumn{2}{|c|}{$\begin{array}{c}\text { Compassionate } \\
\text { care }\end{array}$} & \multicolumn{2}{|c|}{$\begin{array}{l}\text { Perspective } \\
\text { taking }\end{array}$} & \multicolumn{2}{|c|}{$\begin{array}{c}\text { Ability to stand in } \\
\text { someone else's shoes }\end{array}$} & \multirow[t]{2}{*}{$\mathbf{n}$} \\
\hline & & Mean & SD & Mean & SD & Mean & SD & Mean & SD & \\
\hline \multirow[t]{3}{*}{ First } & Female & 111.63 & 8.650 & 42.26 & 4.667 & 58.69 & 6.328 & 10.69 & 2.938 & 35 \\
\hline & Male & 106.71 & 11.678 & 39.21 & 6.542 & 57.79 & 5.309 & 9.71 & 2.840 & 14 \\
\hline & Total & 110.22 & 9.745 & 41.39 & 5.381 & 58.43 & 6.014 & 10.41 & 2.915 & 49 \\
\hline \multirow[t]{3}{*}{ Second } & Female & 110.62 & 10.265 & 41.65 & 5.051 & 57.77 & 6.901 & 11.19 & 2.638 & 26 \\
\hline & Male & 107.93 & 13.135 & 41.21 & 4.995 & 55.29 & 8.713 & 11.43 & 3.413 & 14 \\
\hline & Total & 109.68 & 11.258 & 41.50 & 4.972 & 56.90 & 7.568 & 11.28 & 2.891 & 40 \\
\hline \multirow[t]{3}{*}{ Third } & Female & 115.27 & 9.216 & 43.97 & 4.980 & 59.86 & 6.278 & 11.44 & 3.143 & 66 \\
\hline & Male & 108.38 & 10.818 & 40.41 & 5.852 & 57.79 & 8.028 & 10.17 & 3.413 & 29 \\
\hline & Total & 113.17 & 10.187 & 42.88 & 5.483 & 59.23 & 6.883 & 11.05 & 3.263 & 95 \\
\hline \multirow[t]{3}{*}{ Fourth } & Female & 114.31 & 16.323 & 43.62 & 7.514 & 60.41 & 8.588 & 10.28 & 2.750 & 29 \\
\hline & Male & 114.29 & 10.815 & 43.00 & 6.364 & 60.29 & 4.767 & 11.00 & 3.221 & 17 \\
\hline & Total & 114.30 & 14.400 & 43.39 & 7.044 & 60.37 & 7.347 & 10.54 & 2.919 & 46 \\
\hline \multirow[t]{3}{*}{ Fifth } & Female & 117.77 & 9.097 & 44.85 & 3.964 & 61.56 & 5.734 & 11.36 & 2.951 & 39 \\
\hline & Male & 111.86 & 14.281 & 42.51 & 6.569 & 58.65 & 8.908 & 10.70 & 3.439 & 37 \\
\hline & Total & 114.89 & 12.192 & 43.71 & 5.482 & 60.14 & 7.543 & 11.04 & 3.193 & 76 \\
\hline \multirow[t]{3}{*}{ Total } & Female & 114.35 & 10.755 & 43.48 & 5.274 & 59.79 & 6.701 & 11.08 & 2.950 & 195 \\
\hline & Male & 110.18 & 12.516 & 41.46 & 6.198 & 58.14 & 7.738 & 10.58 & 3.307 & 111 \\
\hline & Total & 112.84 & 11.581 & 42.75 & 5.700 & 59.20 & 7.127 & 10.90 & 3.089 & 306 \\
\hline
\end{tabular}

SD: standard deviation.

TABLE 2. Results of the relationship of overall empathy and each of its components by school year and sex

\begin{tabular}{|c|c|c|c|c|}
\hline Overall empathy & $\mathbf{F}$ & (p) & Eta-squared & Power \\
\hline SY & 2.73 & 0.029 & 0.036 & 0.752 \\
\hline$S$ & 8.05 & 0.005 & 0.026 & 0.807 \\
\hline$S Y^{*} S$ & 0.777 & 0.541 & 0.010 & 0.249 \\
\hline \multicolumn{5}{|c|}{ Compassionate care } \\
\hline SY & 2.45 & 0.045 & 0.032 & 0.788 \\
\hline S & 7.91 & 0.005 & 0.026 & 0.801 \\
\hline$S Y^{*} S$ & 0.796 & 0.529 & 0.011 & 0.254 \\
\hline \multicolumn{5}{|l|}{ Perspective taking } \\
\hline SY & 2.097 & 0.081 & 0.028 & 0.620 \\
\hline S & 3.553 & 0.060 & 0.012 & 0.468 \\
\hline$S Y^{*} S$ & 0.336 & 0.854 & 0.005 & 0.126 \\
\hline \multicolumn{5}{|c|}{ Standing in someone else's shoes } \\
\hline SY & 0.758 & 0.554 & 0.010 & 0.243 \\
\hline S & 0.966 & 0.326 & 0.003 & 0.165 \\
\hline$S Y^{*} S$ & 0.926 & 0.449 & 0.012 & 0.293 \\
\hline
\end{tabular}

(p) Probability of making a type I error.

* Symbol for the interaction between SY and $S$.

SY: school year; S: sex. 
relation to $S$, highly significant differences were observed ( $F=7.91, p=0.005)$, and the highest value was recorded in women (Table 1, Figure 1.b). For the PT component, the ANOVA showed no significant differences in any of the factors or the interaction; therefore, no differences were observed between men and women and among the school years (Table 1, Figure 1.c). Lastly, the situation for the ASSES component was similar to that of the component analyzed above (Table 1, Figure 1.d). Results observed here should be interpreted with caution, especially when the Etasquared and the power values were not entirely satisfactory.

The PD of E in first year students was estimated to be 30.83 (140-109.17): the difference in empathy between fifth and first year students (114.82-100.17) was 5.65 points; this means that only $18.33 \%$ of the total possible development potential was covered.

The PD of the CC component in first year students was estimated to be 5.29 (49-43.71): the difference in empathy between fifth and first year students (43.71-41.39) was 2.32 points; this means that only $43.86 \%$ of the total possible development potential was covered.

The development potential of the PT component was observed to be 9.86 points (7060.14): the difference between first and fifth year students (60.14-58.43) was 1.71 points; as a result, the development potential of this component was $17.34 \%$. Lastly, it was observed that for the ASSES component, the development potential was 9.96 (21-11.04); therefore, the percentage of coverage of the total development potential was $0.63 \%$.

Figure 1 (1.a-1.d) is a graphic representation of the mean values for the SY and S factors. Empathy and CC increase with school years, and differences in such development are observed between both sexes. Certainly, such behavior is analyzed based on the fact that there are statistical differences between sexes in terms of $\mathrm{E}$ and $\mathrm{CC}$.

\section{DISCUSSION}

The results of this study show that women had higher E and CC levels than men (significant differences) and only had absolute value differences in relation to the PT and ASSES components. The higher levels observed in the CC component, which is related to emotional empathy, indicate that students have a compassionate basis. Other studies conducted in different courses from several universities and Latin American countries also showed such contrast between sexes in favor of women. $6,10,17,20-23$ Likewise, the study by Varela et al. ${ }^{19}$ found such difference in dental students from Latin American universities.

In addition, empathy progressed along school years. These results were consistent with those

FIGURE 1. Distribution of overall empathy and each of its components in the school year and sex factors

Overall empathy
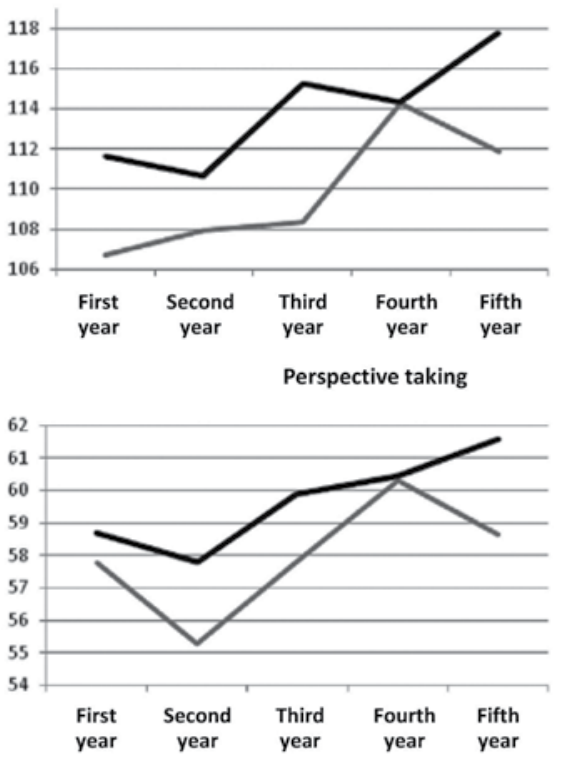
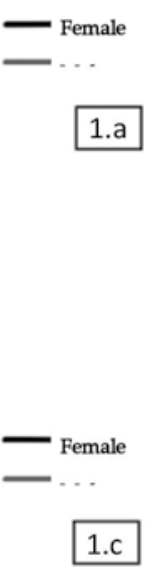

Compassionate care
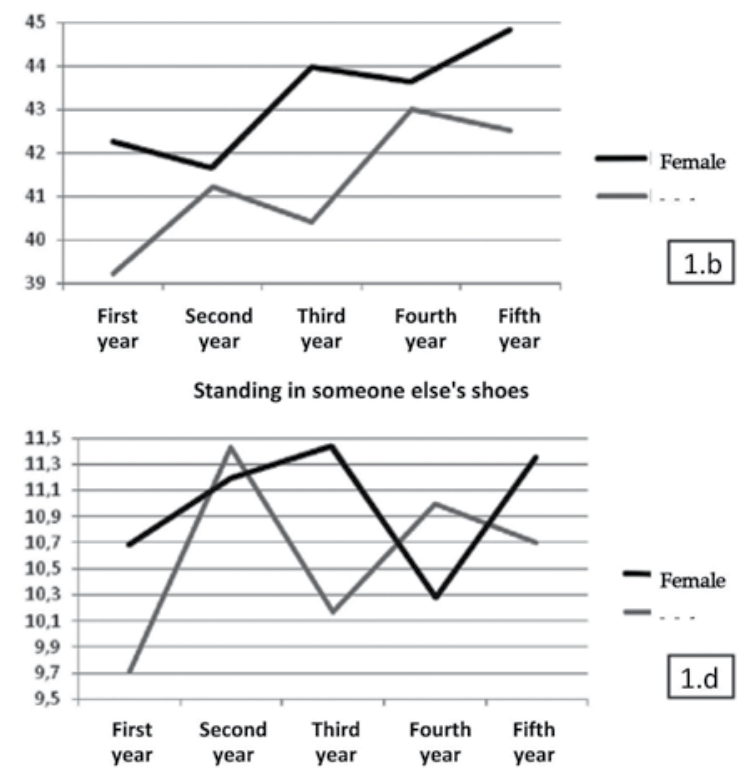
obtained by Erazo et al. ${ }^{24}$ and by Howard et al. ${ }^{25}$ in dental students, in whom empathy increased towards the final years of school, whereas the results in medical students published by Hojat et al. ${ }^{11}$ and by Díaz-Narváez et al. ${ }^{6}$ indicated a process of erosion of empathy (decrease in empathy with school years). Silva et al. ${ }^{20}$ found that the progression of school years did not affect the empathy of students in the Dominican Republic. The study by Varela et al..$^{19}$ in dental students from the UCC observed that empathy and its components increased until third year, reduced in fourth year and increased again in fifth year, except for the ASSES component, which reduced with school years.

As mentioned before, empathy is the synthesis of two components: cognitive and emotional processing. The ability to understand the experience and feelings of other people and the capability to observe and understand the world from another person's perspective are related to the cognitive component, while the affective aspect is related to the ability to share the experiences of others, ${ }^{1}$ although this approach is strictly for analysis purposes. ${ }^{16}$ The statistical differences observed in the CC component showed that the SY factor reflected its increase, and progression was estimated at $43.86 \%$ of its total possible potential, i.e., greater than the other components. This is consistent with the studies by Díaz-Narváez et al. ${ }^{1}$ Calzadilla-Nuñez ${ }^{16}$ suggested that compassion was highly associated with morals, that the combination of emotion and morals was closely related to compassion, and that subjects with important moral foundations, embedded in a culture of established principles of respect and consideration for others should not experience changes in this component, especially, a reduction of empathy caused by the presence of suffering, as proposed by other lines of research that stated that "the erosion of empathy occurred with the progression of school years."11

The results of this study showed that affective empathy tended to increase. These findings would demonstrate that the empathic basis of the emotional aspect is relevant and that it is necessary to develop the cognitive component through specific actions in relation to the academic program. This aspect is encouraged during students' training as they participate in activities and projects related to voluntary service, ecclesiastic campus activities, social work, and specific courses. They work in direct contact with patients -and therefore, with human suffering first hand, not in theory- since they start their academic program, both in individual and family/group settings, which allows them to develop an emotional connection.

Cognitive components (PT and ASSES) showed low values and scarce PD coverage levels.

Empathy is the result of subjects' ontogenetic and evolutionary development in interaction with their environment; therefore, there may be specific factors that encompass and modulate empathy in interaction with each subject's specific ontogenetic factors, given that several factors have been observed to affect the determination of an empathic response. ${ }^{16}$ It will be necessary to further look into these factors in order to complete an empathic diagnosis and the behavior of empathy levels in relation to sex and school year. Calzadilla-Nuñez et al. ${ }^{16}$ proposed that the diagnosis process will help to identify whether overall empathy or any of its components are under development, have stopped or simply deteriorated, and this may guide the training response strategy so as to improve empathy levels. In the end, these results provide information that will allow to establish specific strategies aimed at promoting the development of empathy during students' professional training.

\section{CONCLUSIONS}

Overall empathy, and the CC component specifically, increased from the first through fifth year of school (and it was higher among women compared to men), which evidenced the progressive development of the affective component of empathy. The development potential of overall empathy and cognitive components showed little progression.

\section{REFERENCES}

1. Díaz-Narváez VP, Alonso-Palacio LM, Caro SE, Silva M, et al. Compassionate Care, Component of the Construct Empathy in Medical Students in Colombia and Dominican Republic. Acta Med Mediterr. 2017; 33:115-21.

2. Hojat M, Mangione S, Nasca TJ, Cohen MJM, et al. The Jefferson Scale of Physician Empathy: Development and Preliminary Psychometric Data. Educ Psychol Meas. 2001; 61(2):349-65.

3. Gallangher HL, Frith CD. Functional imaging of "theory of mind". Trends Cogn Sci. 2003; 7(2):77-83.

4. Wellberry C, Saunders PA, Kureshi S, Visconti A. Medical Students' Empathy for Vulnerable Groups: Results From a Survey and Reflective Writing Assignment. Acad Med. 2017; 92(12):1709-14.

5. Martínez González C, Tasso Cereceda M, Sánchez Jacob M, Riaño Galán I. Pediatras sólidos en tiempos líquidos. Reanimando la profesionalidad. An Pediatr (Barc). 2017; 86(6):354.e1-4.

6. Díaz-Narváez VP, Alonso Palacio LM, Caro SE, Silva MG, 
et al. Orientación empática de estudiantes de medicina en tres universidades de Barranquilla, Colombia y en una universidad de la Republica Dominicana. Arch Argent Pediatr. 2014; 112(1):41-9.

7. Mangione S, Kane GC, Caruso JW, Gonnella JS, et al. Assessment of empathy in different years of internal medicine training. Med Teach. 2002; 24(4):370-3.

8. Díaz-Narváez VP, Muñoz-Gámbaro G, Duarte-Gómez $\mathrm{N}$, Reyes-Martínez MC, et al. Empatía en estudiantes de enfermería de la Universidad. Mayor, Sede Temuco, IX región, Chile. Aquichan. 2014; 14(3):388-402.

9. Cruz Hernández M. Un renovado reto en la formación pediátrica: la relación médico-paciente familia. Educ Med. 2004; 7(4):119-24.

10. BilbaoJL,IglesiasJE, Díaz-Narváez VP, Crespo-CamachoE, et al. Orientación empática en estudiantes de medicina de las Universidades Librey San Martin, Barranquilla, Colombia. Investigación original. Rev Fac Med. 2015; 63(4):657-63.

11. Hojat M, Vergare M, Maxwell $K$, Brainard G, et al. The devil is the third year: a longitudinal study of erosion of empathy in medical school. Acad Med. 2009; 84(9):1182-91.

12. Chen D, Lew R, Hershman W, OrlanderJ. A Cross-sectional Measurement of Medical Student Empathy. J Gen Intern Med. 2007; 22(10):1434-8.

13. Roh MS, Hahm B, LeeDH, Suh DH. Evaluation of Empathy Among Korean MedicalStudents: A Cross-Sectional Study Using the Korean Version of the Jefferson Scale of Physician Empathy. Teach Learn Med. 2010; 22(3):167-71.

14. Magalhães E, Salgueira AP, Costa P, Costa MJ. Empathy in senior year and first year medical students: a cross-sectional study. BMC Med Educ. 2011; 11:52.

15. Tavakol S, Dennick R, Tavakol M. Empathy in UK medical year and specialty interest. Educ Prim Care. 2011;22(5):297303.

16. Calzadilla-Núñez A, Díaz-Narváez VP, Dávila Pontón Y, Aguilera-Muñoz J, et al. Erosión empática durante la formación médica según el género. Estudio transversal. Arch Argent Pediatr. 2017; 115(6):556-61.

17. Carrasco DE, Bustos A, Díaz-Narváez V. Orientación empática en estudiantes de odontología chilenos. Rev Estomatol Herediana. 2012; 22(3):145-51.

18. Alcorta-Garza A, González-Guerrero JF, Tavitas-Herrera SE, Rodríguez-Lara FJ, et al. Validación de la Escala de Empatía Médica de Jefferson en Estudiantes de Medicina Mexicanos. Salud Ment (Mex). 2005; 28(5):57-63.

19. Varela T, Villaba R, Gargantini P, Quinteros S, et al. Niveles de orientación empática en estudiantes de Odontología de la Universidad Católica de Córdoba, Argentina (UCC). Claves Odontol. 2012; 19(70):15-22.

20. Silva M, Arboleda CastilloJ, Díaz-Narváez VP. Orientación empática en estudiantes de odontología de la Universidad Central del Este. Odontoestomatología. 2013; 15(22):24-33.

21. Bullen M, Salazar L, Díaz-Narváez VP. Orientaciónempática en estudiantes de odontología de la Universidad de Panamá (República de Panamá). Salud, Barranquilla. 2015;31(2):26675.

22. Díaz-Narváez VP, Salas-Alarcón D, Bracho-Milic F, Ocaranza-Ozímica J. Empatía en estudiantes de Kinesiología. Universidad Mayor, sede Temuco, Chile. Revista Ciencias de la Salud. 2015; 13(3):383-93.

23. Rivera Ugalde I, Arratia Bulboa R, Zamorano Arancibia A, Díaz Narváez VP. Evaluación del nivel de orientación empática en alumnos de odontología. Salud Uninorte. 2011; 27(1):63-72.

24. Díaz-Narváez VP, Erazo Coronado AM, BilbaoJL, González $\mathrm{F}$, et al.Empathy Level of DentalStudent of Central America and the Caribbean. Health. 2015; 7(12):1678-86.

25. Howard Mora M, Navarro Rodríguez S, Rivera Ugalde I, Zamorano Arancibia A, et al. Medición del nivel de orientación empática en el estudiantado de la Facultad de Odontología, Universidad de Costa Rica. Publicación Científica Facultad de Odontología UCR. 2013; 15:21-9. 